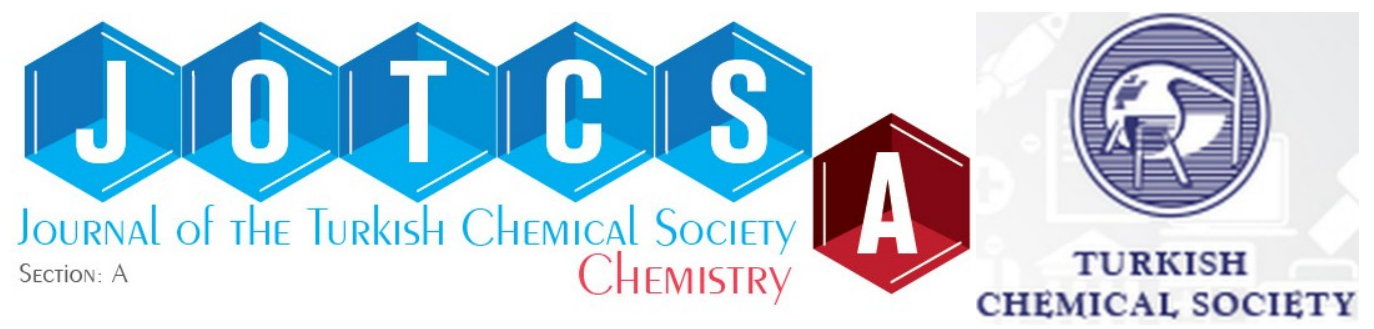

\title{
Biosorption Studies of Mushrooms for Two Typical Dyes
}

\author{
Ayfer YILDIRIM ${ }^{*} \square$, Hilal ACAY $2 \square$ \\ ${ }^{1}$ Vocational Higher School of Health Services, Mardin Artuklu University, Mardin, Turkey \\ ${ }^{2}$ Department of Nutrition and Dietetics, Faculty of Health, Mardin Artuklu University, Mardin, Turkey
}

\begin{abstract}
This study investigated the adsorption behaviour of two cationic dyes, methylene blue (MB) and malachite green (MG) onto Pleurotus ostreatus, Armillaria tabescens, and Morchella conica mushrooms. The effects of contact time, initial dye concentration, and solution $\mathrm{pH}(3-11)$ were also determined. The adsorption on all mushrooms attained equilibrium within 120 min for both MB and MG. To evaluate the experimental kinetics data, the pseudo-first-order, pseudo-second-order, and intraparticle diffusion kinetics equations were utilised. The pseudo-first-order kinetic model demonstrated a good fit with all adsorption kinetics. The Langmuir and Freundlich isotherm models were used to analyse the mechanism of the adsorption isotherm. The adsorption equilibrium isotherm was in a good agreement with the Freundlich model. Thermodynamic parameters such as $\Delta \mathrm{H}$ enthalpy variation, $\Delta \mathrm{S}$ entropy variation, and $\Delta \mathrm{G}$ free Gibbs energy variation were calculated at $303-323 \mathrm{~K}$. The results suggested that the Pleurotus ostreatus mushroom was the most suitable adsorbent for both cationic dyes' removal.
\end{abstract}

Keywords: Mushroom, biosorption, methylene blue, malachite green, thermodynamic parameters.

Submitted: June 21, 2019. Accepted: January 19, 2020.

Cite this: Yıldırım A, Acay H. Biosorption Studies of Mushrooms for Two Typical Dyes. JOTCSA. 2020; 7(1): 295-306.

DOI: https://doi.org/10.18596/jotcsa.581007.

*Corresponding author. E-mail: ayferyildirim@artuklu.edu.tr. Tel: +90 482213 4002/7261

\section{INTRODUCTION}

Dyes that are used in the food, textiles, paper, plastics, cosmetics, pharmaceuticals, and other industries generally have carcinogenic, mutagenic, and teratogenic properties. This is why they can cause serious environmental problems $(1,2)$.

Among the techniques used to remove dye molecules from wastewater, adsorption has been recognised as the most effective one as it is proven to be practical and low-cost and have high efficiency (3). However, it has been reported that most sufficient adsorbents such as activated carbon are costly in overcoming the pollution problems of dyes. Thus, the high cost of commercial adsorbents has encouraged researchers to investigate non-toxic, low-price, biodegradable, and environment-friendly alternative biosorbent materials (4). In general, these materials include natural biosorbents derived from waste materials from industries and agriculture. White rot fungi are the most commonly used organisms in biological treatment studies in the field of waste and environmental biotechnology (5). Among them, the Basidiomycetes group takes a great part in the organic compound oxidation of very different molecular structures with various enzymes synthesised mainly by the laccase enzyme, which increases because of intensive industrial activity and environmental annihilation and pollution (6). These mushrooms draw great attention with their properties and have been used in many biotechnological studies. The most commonly used white fungi species include Phanerochaete chrysosporium, Coriolus versicolor, and Trametes versicolor as well as Funalia trogii, Pleurotus ostreatus, $P$. sajor-caju and $P$. eryngii, $(7,8)$. It has been reported in the studies in the literature that these mushrooms have been widely used all over the world to eliminate the color of textile wastewaters (9-11).

Pleurotus ostreatus (M1) and Armillaria tabescens (M2), which are the mushroom species used in the present study, are white-rot fungi and in the 
basidiomycetes group while Morchella conica (M3), the other species used in this study, is not whiterot fungi and in the ascomycetes group. To the best of our knowledge, no study has been reported on the adsorption behaviours of Methylene blue (MB) and Malachite green (MG), both cationic dyes, by these three edible fungi (M1, M2, and $\mathrm{M3})$. The influence of kinetics, contact time, $\mathrm{pH}$ and initial dye concentration on the adsorption capacity was evaluated and discussed. By using the Freundlich and Langmuir isotherms, the equilibrium data were analysed and characteristic parameters were determined.

\section{MATERIALS AND METHODS}

\section{Preparation of the biosorbent}

The M1, M2 and M3 mushrooms used in this study were obtained from the province of Mardin in Turkey between April-May 2016. The mushrooms were identified according to Phillips (1994) using ecological, macroscopic and microscopic data. The mushrooms were dried at room temperature for four days. The dried mushroom samples were pulverised in a mixer to be used in the experimental studies.

\section{Preparation of the adsorbate}

MB was purchased from Merck while MG was purchased from Sigma. The other reagents used were of analytical grade and all solutions were prepared with distilled water.

\section{Characterisation methods}

The characterisation of the mushrooms was achieved by differential scanning calorimetry (DSC) measurements that were performed on a TA Instruments DSC250 with a heating rate of $10^{\circ} \mathrm{C}$ $\min ^{-1}$ under nitrogen atmosphere and Fouriertransform infrared (FTIR) spectra which were recorded on ALPHA Bruker spectrometer with a Platinum-ATR accessory (ZnSe crystal).

\section{Kinetic and equilibrium biosorption studies}

$1000 \mathrm{mg} \mathrm{L}^{-1}$ of the dyes were prepared in distilled water to obtain stock solutions and, by using the stock solutions, the required concentrations were achieved with dilution. The current $\mathrm{pH}$ was adjusted by $0.1 \mathrm{~N} \mathrm{HCl}$ and $0.1 \mathrm{~N} \mathrm{NaOH}$ solutions.

To investigate the kinetics of the biosorption ability of the three fungal biosorbents on the MB and MG dyes, batch experiments were carried out typically, using $50 \mathrm{mg}$ biomasses, $50 \mathrm{ml}$ of dye solutions (25-75 $\mathrm{mg} \mathrm{L}^{-1}$ ) in $100 \mathrm{~mL}$ glass flask with an agitation speed of $120 \mathrm{rpm}$ (GFL 1083 model thermostatted shaker) at natural $\mathrm{pH}$ at $303 \mathrm{~K}$ for certain times $(30,60,90,120,150,180,240$ min). The dyes' concentration in aqueous solution was measured at a max wavelength of 632 (MB) and 617 (MG) nm using PG T80+ Model UV-Visible spectrophotometer.

The concentration retained in the fungal biomasses phase was calculated by the following equation:
$q=\left(C_{0}-C_{e}\right) V / m$

Where $\mathrm{q}$ is the amount of the dye adsorbed per unit weight of the biosorbent $\left(\mathrm{mg} \mathrm{g}^{-1}\right), \mathrm{C}_{0}$ is the initial concentration of the dye $\left(\mathrm{mg} \mathrm{L}^{-1}\right), \mathrm{C}_{e}$ is the concentration of the dye in solution at equilibrium time $\left(\mathrm{mg} \mathrm{L}^{-1}\right), \mathrm{V}$ is the solution volume ( $\mathrm{L}$ ) and $\mathrm{m}$ is the weight of the mushrooms $(\mathrm{g})$.

\section{RESULTS AND DISCUSSION}

\section{Characterisation of mushrooms}

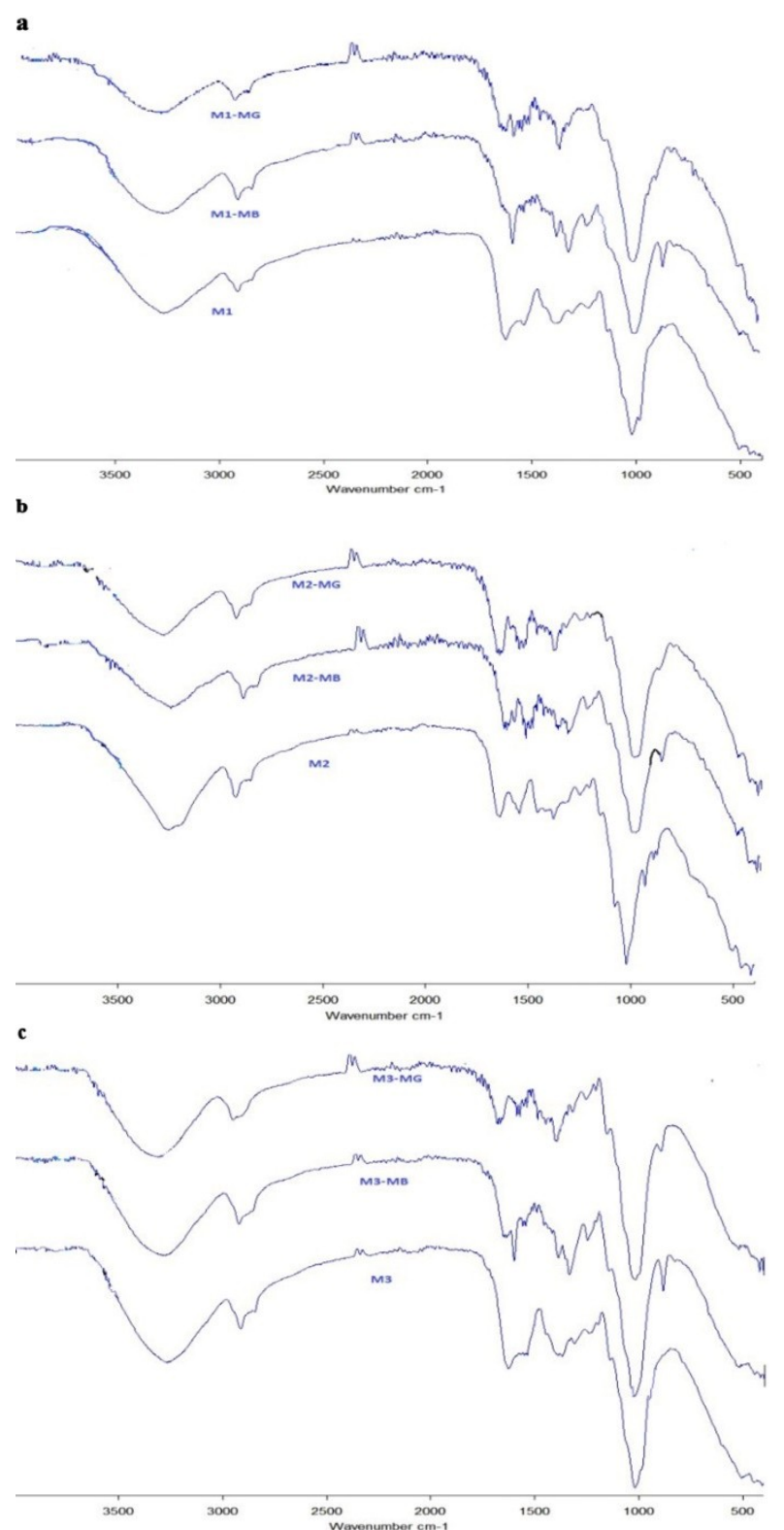

Figure 1. FTIR spectra of $M 1, M 2, M 3$ and $M B, M G$ loaded $\mathbf{a}: M 1 \mathbf{b}: M 2 \mathbf{c}: M 3$.

The chemical structures of the mushrooms were confirmed by determining the functional groups in their structures using FTIR spectroscopic analysis (Fig.1a-c.). The FTIR spectra of the mushrooms were found to demonstrate characteristic amine absorption peak around $1600 \mathrm{~cm}^{-1}$. The $\mathrm{C}-\mathrm{H}$ stretch peak around $2900 \mathrm{~cm}^{-1}$ and broad peaks at $3500-3100 \mathrm{~cm}^{-1}$ are attributed to $\mathrm{N}-\mathrm{H}$ and $\mathrm{OH}-\mathrm{O}$ stretching. Besides, the amide I peak (1700-1600 
$\mathrm{cm}-1$ ) is known to provide information about the $\mathrm{C}=\mathrm{O}$ stretching of amide groups (Fig. 1a-c.) $(12,13)$. According to Figure $1 \mathrm{a}-\mathrm{c}$, the peak at $1633.93 \mathrm{~cm}^{-1}$ (M1), $1635.93 \mathrm{~cm}^{-1}$ (M2) and $1635.65 \mathrm{~cm}^{-1}$ (M3) is typical of a $\mathrm{C}-\mathrm{N}$ and $\mathrm{N}-\mathrm{H}$ deformations that shifted to $1597.25 \mathrm{~cm}^{-1}$, $1636.48 \mathrm{~cm}^{-1}$ and $1633.36 \mathrm{~cm}^{-1}$ after MB adsorption and shifted to $1635.45 \mathrm{~cm}^{-1}, 1646.60$ $\mathrm{cm}^{-1}$ and $1647.09 \mathrm{~cm}^{-1}$ after MG adsorption.

The presence of peaks at $1393.69 \mathrm{~cm}^{-1}, 1326.11$ $\mathrm{cm}^{-1}$ (M1), $1374.93 \mathrm{~cm}-1,1339.26 \mathrm{~cm}^{-1}$ (M2) and $1374.58 \mathrm{~cm}^{-1}, 1317.73 \mathrm{~cm}^{-1}$ (M3) is attributed to $\mathrm{COO}^{-}$vibration in carboxylates that shifted to $1386.11 \mathrm{~cm}^{-1}, 1328.78 \mathrm{~cm}^{-1}$; $1386.99 \mathrm{~cm}^{-1}$, $1338.17 \mathrm{~cm}^{-1} ; 1386.49 \mathrm{~cm}^{-1}, 1333.90 \mathrm{~cm}^{-1}$ and increased after the adsorption of $\mathrm{MB}$ and shifted to $1395.97 \mathrm{~cm}^{-1}, 1339.18 \mathrm{~cm}^{-1} ; 1396.16 \mathrm{~cm}^{-1}$, $1339.38 ; 1396.43 \mathrm{~cm}^{-1}, 1339.60 \mathrm{~cm}^{-1}$ after MG adsorption which indicated the presence of $M B$ and MG molecules adsorbed ( $\mathrm{C}=\mathrm{C}$ of the alkyl $\mathrm{R}-)$. The peaks observed at $1028.70 \mathrm{~cm}^{-1}$ (M1), 1021.50 $\mathrm{cm}^{-1}$ (M2) and $1026.94 \mathrm{~cm}^{-1}$ (M3) $\mathrm{cm}^{-1}$ are attributed to the $\mathrm{C}-\mathrm{O}$ stretching of alcohol and carboxylic acids that shifted to $1017.76 \mathrm{~cm}^{-1}$, $1006.14 \mathrm{~cm}^{-1}$ and $1026.94 \mathrm{~cm}^{-1}$ after the adsorption of $\mathrm{MB}$ and shifted to $1008.46 \mathrm{~cm}^{-1}$, $1020.71 \mathrm{~cm}^{-1}$ and $1012.88 \mathrm{~cm}^{-1}$ after the adsorption of MG dye molecules (14-18).

The peak at $899.82 \mathrm{~cm}^{-1}$ (M2) shifted to 884.09 $\mathrm{cm}^{-1}$ after MB adsorption and shifted to $878.72 \mathrm{~cm}^{-}$ 1 after MG adsorption while new peaks at 883.66 $\mathrm{cm}^{-1}$ (M1) and $884.52 \mathrm{~cm}^{-1}$ (M3) were formed after the adsorption of $\mathrm{MB}$ at $885.14 \mathrm{~cm}^{-1}$ (M1), 867.01 $\mathrm{cm}^{-1}$ (M3) after the adsorption of MG belongs to the $\mathrm{C}-\mathrm{H}$ out of plane bending vibration of an aromatic ring (Fig. 1a-c.) (19-21).

The change and shift in the intensity of the characteristic peaks in the hybrid spectra after adsorption could also be evidence of interactions between the functional groups of the mushrooms and dye molecules (22).

Figure 2 shows the DSC measurements which determined the thermal behaviour of the mushrooms. The samples were heated from $-50^{\circ} \mathrm{C}$ to $250{ }^{\circ} \mathrm{C}$ at a heating rate of $10^{\circ} \mathrm{C} / \mathrm{min}$ under an inert atmosphere of nitrogen. There was an endothermic peak of each mushrooms appearing at $92.39{ }^{\circ} \mathrm{C}$ (M1), 82.56 and $143.80{ }^{\circ} \mathrm{C}$ (M2) and $92.32{ }^{\circ} \mathrm{C}$ (M3) while enthalpy was $236.36 \mathrm{~J} / \mathrm{g}$ (M1), 169.39 and $4.1701 \mathrm{~J} / \mathrm{g}$ (M2) and $268.51 \mathrm{~J} / \mathrm{g}$ (M3), respectively. The endothermic process mainly contained hydrogen bond dissociation and water loss. Thus, the endothermic peak of $\mathrm{M} 2$ presented the highest value due to slow water loss, increasing thermal stability. This may be caused by the fact that $M 2$ is from a different group of species and has a different chemical composition and physical properties (such as density) $(23,24)$.
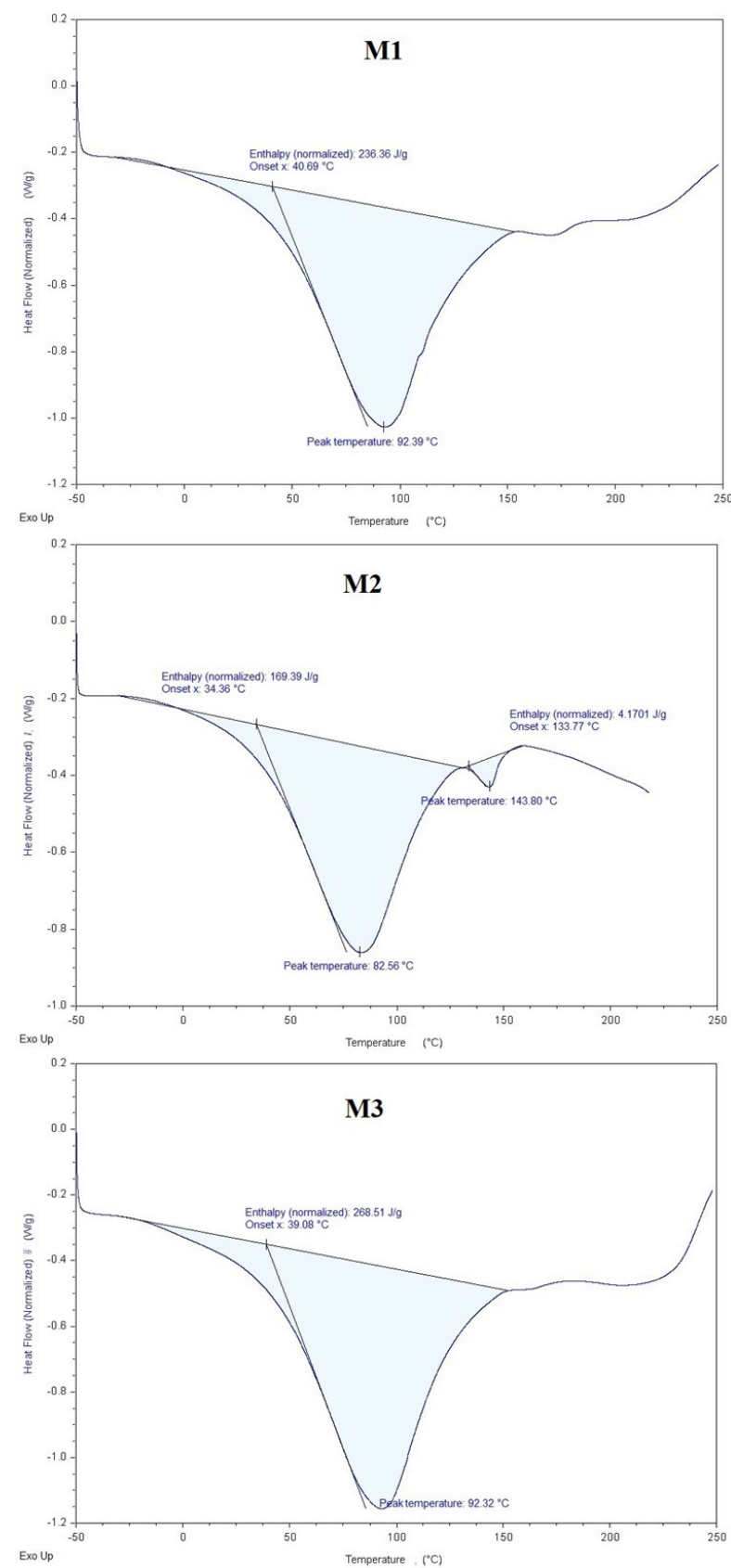

Figure 2. The DSC plots for the mushrooms investigated.

\section{The effect of contact time}

The adsorption capacity of two cationic dyes increased with contact time and reached equilibrium about 240 min with a fixed $V=50 \mathrm{~mL}$, $\mathrm{C}_{0}=25,50,75 \mathrm{mg} \mathrm{L}^{-1}, \mathrm{~m}=0.01 \mathrm{~g}$ and $\mathrm{r}=120 \mathrm{rpm}$ (Fig.3a,b). 


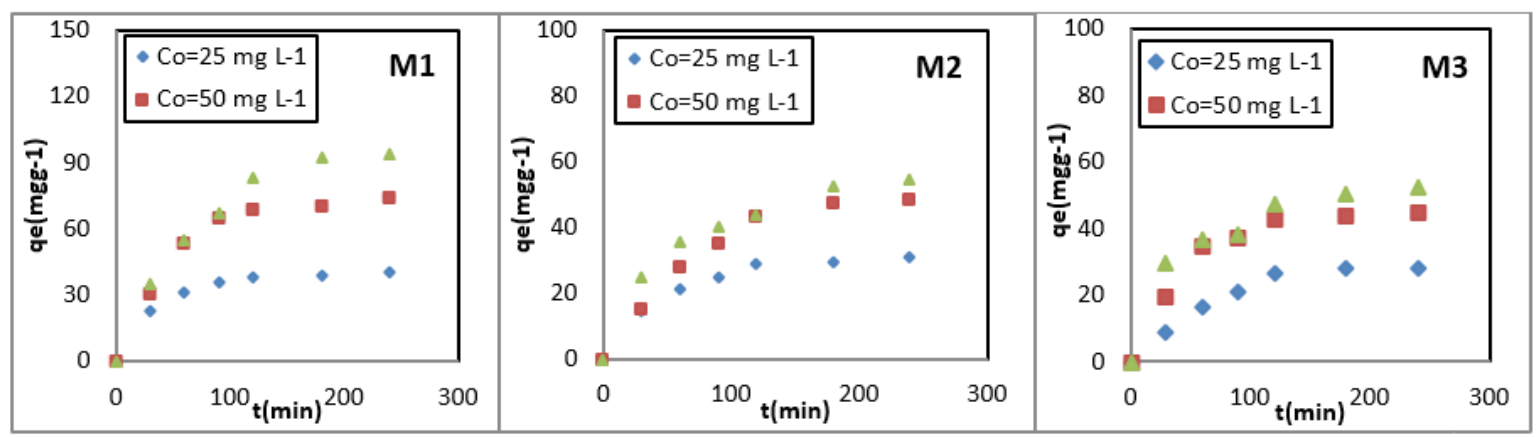

a

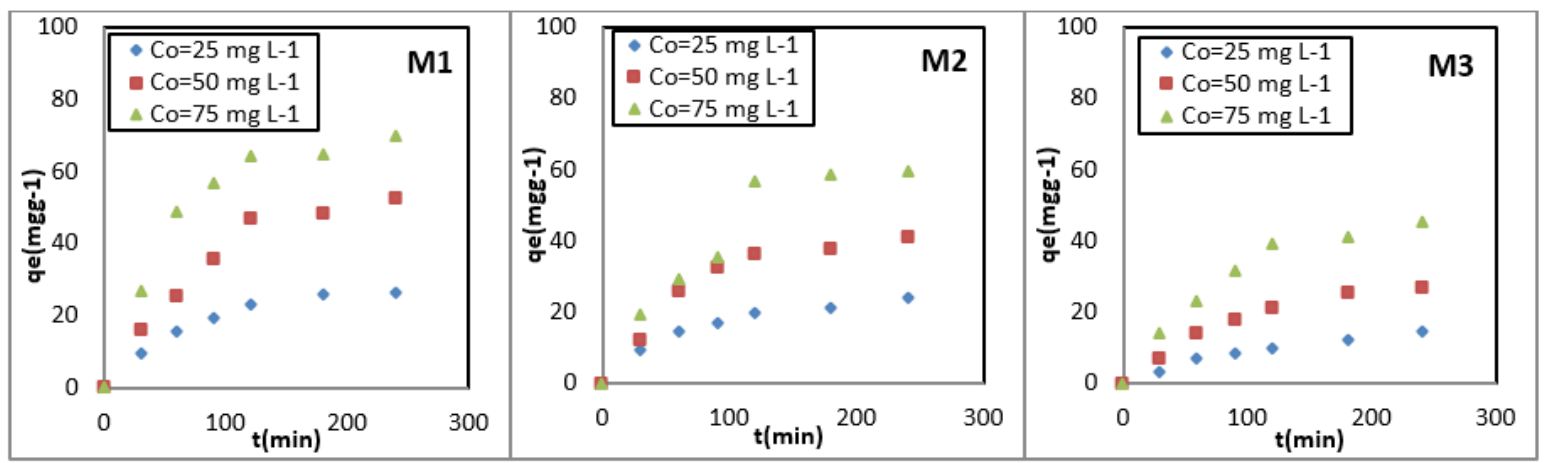

b

Figure 3. Effect of contact time on the adsorption of a: $M B$, b: $M G$ onto $M 1, M 2, M 3$.

According to Figure $3 a-b$, the $q_{e}$ was (for $\mathrm{Co}=25$, $50,75 \mathrm{mg} \mathrm{L}^{-1}$ ) 38.48, 68.77 and $82.81 \mathrm{mg} \mathrm{g}^{-1}$ for $\mathrm{M} 1 ; 28.96,43.20,43.90 \mathrm{mg} \mathrm{g}^{-1}$ for $\mathrm{M} 2$ and 26.63 , $36.45,38.47 \mathrm{mg} \mathrm{g}^{-1}$ for $M 3$ with the adsorption of MB while it was $23.10,47.02,64.13 \mathrm{mg} \mathrm{g}^{-1}$ for $M 1$, $19.80,36.17,56.80 \mathrm{mg} \mathrm{g}^{-1}$ for $\mathrm{M} 2$ and 9.98 , $20.92,39.28 \mathrm{mg} \mathrm{g}^{-1}$ for $M 3$ with the adsorption of $M G$ respectively. This result suggests that $M 1$ is a more appropriate adsorbent than $M 2$ and $M 3$ $(M 1>M 2>M 3)$ for the effective removal of both MB and $M G$ dyes. Besides, Table 4 shows the comparison of the adsorption capacities of MB and MG cationic dyes onto M1, M2, M3 with the biosorbents in the literature.

\section{Effect of pH}

$\mathrm{pH}$ can significantly affect the adsorption process. To study the influence of $\mathrm{pH}$ on the adsorption capacity of the mushrooms, experiments were performed under the $\mathrm{pH}$ range from 3 to 11 . It was found that the adsorption amount of MB increased with increasing $\mathrm{pH}$ from 3 to 11 while MG adsorption increased rapidly at a low $\mathrm{pH}$ value (36 ) and increased further in the range of $\mathrm{pH}$ from 6 to 12 (Fig. 4a,b). At a low pH (in acidic media), repulsion activities occurred greatly between cationic dyes (MB, MG) ions and positively charged groups on the surface of the mushrooms. On the contrary, with increasing $\mathrm{pH}$, electrostatic attractions between cationic dye ions and negatively charged sites on mushrooms' surface were enhanced both cationic dyes adsorption (2528). These results indicate that the adsorption of $\mathrm{MG}$ is more influenced by $\mathrm{pH}$ change than the adsorption of MB on the surface of mushrooms.
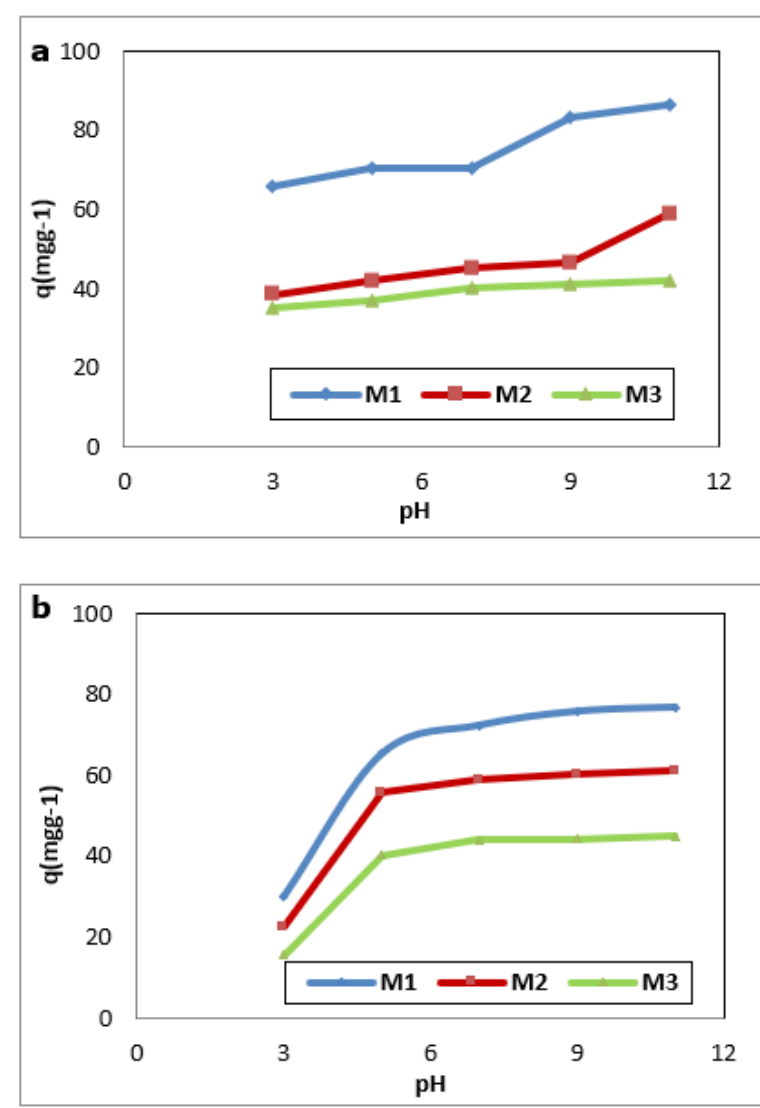

Figure 4. Effect of $\mathrm{pH}$ on the adsorption a:MB, b: $M G$ on the $M 1, M 2, M 3$.

\section{Evaluation of biosorption kinetics}

Two kinetic models, namely pseudo-first-order equation and pseudo-second-order equation were used to investigate the adsorption kinetic 
behaviors of MB and MG onto three mushrooms. To estimate the suitability of the models, it is necessary to introduce the correlation coefficient $(R \sim 1)$. The higher $R^{2}$ value indicates a more applicable model to the kinetics of dye adsorption.

The pseudo-first-order kinetic model is expressed by the equation 1 (29):

$$
\log \left(q_{e}-q_{t}\right)=\log \left(q_{e}\right)-k_{1 t}
$$

where $q_{e}$ and $q_{t}$ refer to the amount of $M B$ and $M G$ adsorbed ( $\left.\mathrm{mg} \mathrm{g}^{-1}\right)$ at equilibrium and at any time $\mathrm{t}(\mathrm{min})$, respectively, and $\mathrm{k}_{1}$ is the equilibrium rate constant of pseudo-first-order $\left(\mathrm{min}^{-1}\right)$. $\mathrm{k}_{1}$ is the equilibrium rate constant of pseudo-firstorder model which was calculated by the slope and intercept of the plot of $\log \left(q_{e}-q_{t}\right)$ versus $t$ (Fig. $5 a, b)$.

The pseudo-second-order model which is expressed by equation 2 (30):

$t / q t=1 / k_{2} q^{2} e+t / q_{e}$

Where, $\mathrm{k}_{2}$ is the equilibrium rate constant of pseudo-second-order $\left(\mathrm{g} \mathrm{mg}^{-1} \mathrm{~min}^{-1}\right)$ which can be determined by the slope and intercept of the plot of $t / q_{t}$ versus $t$ (Fig. 6a,b).
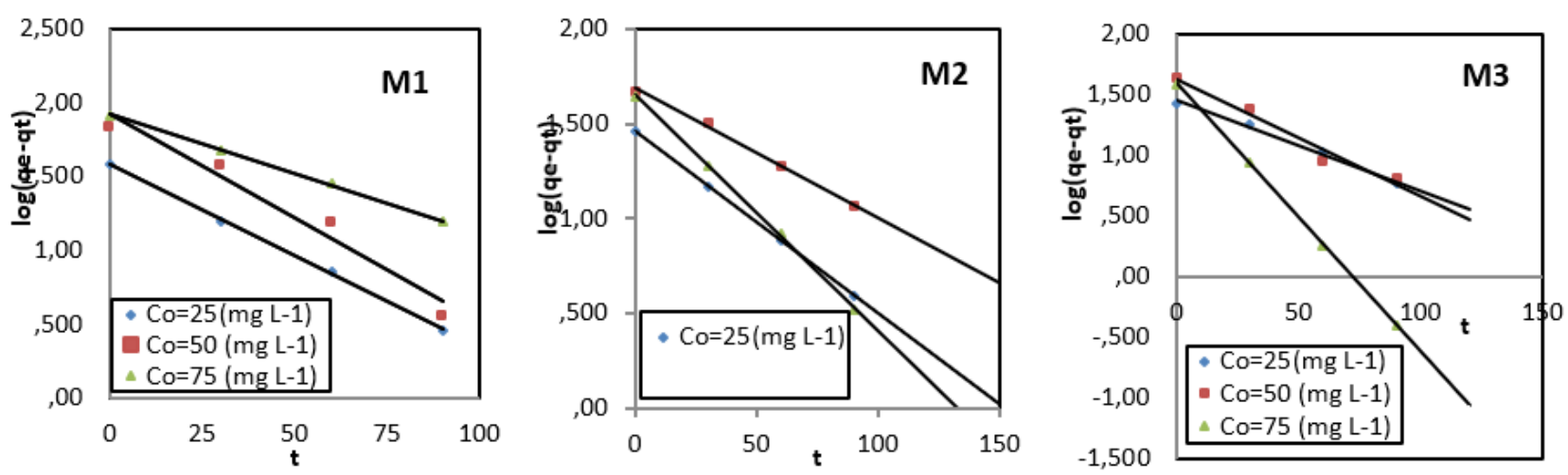

a
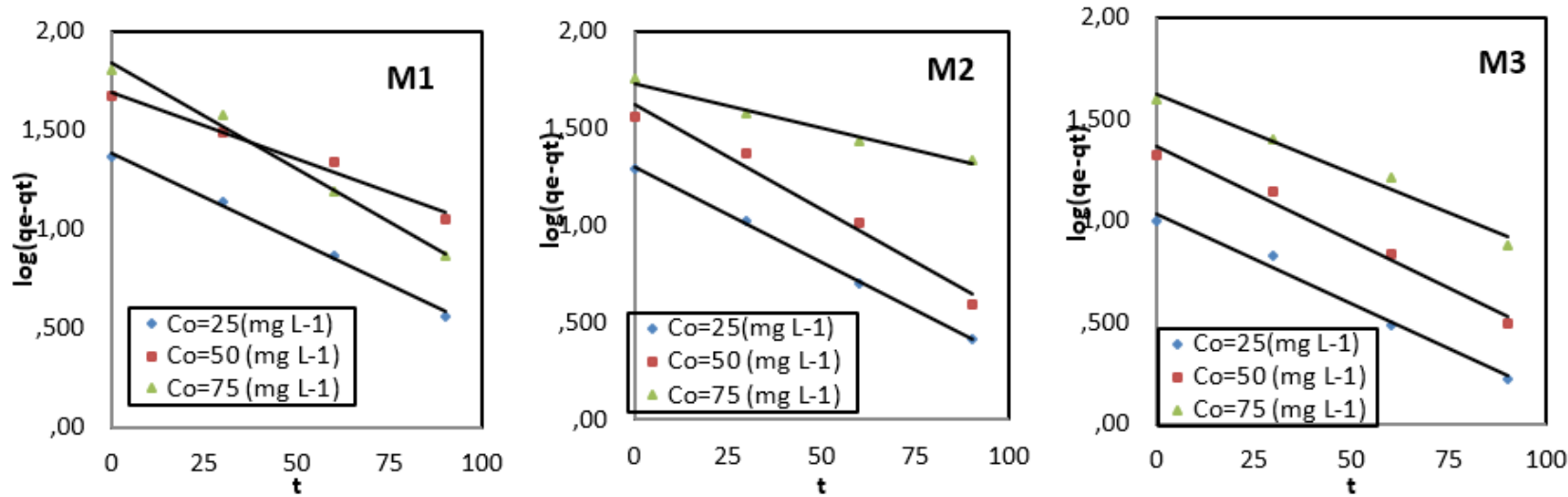

b

Figure 5. Plots for the pseudo-first-order kinetic model a:MB adsorption, b:MG adsorption. 

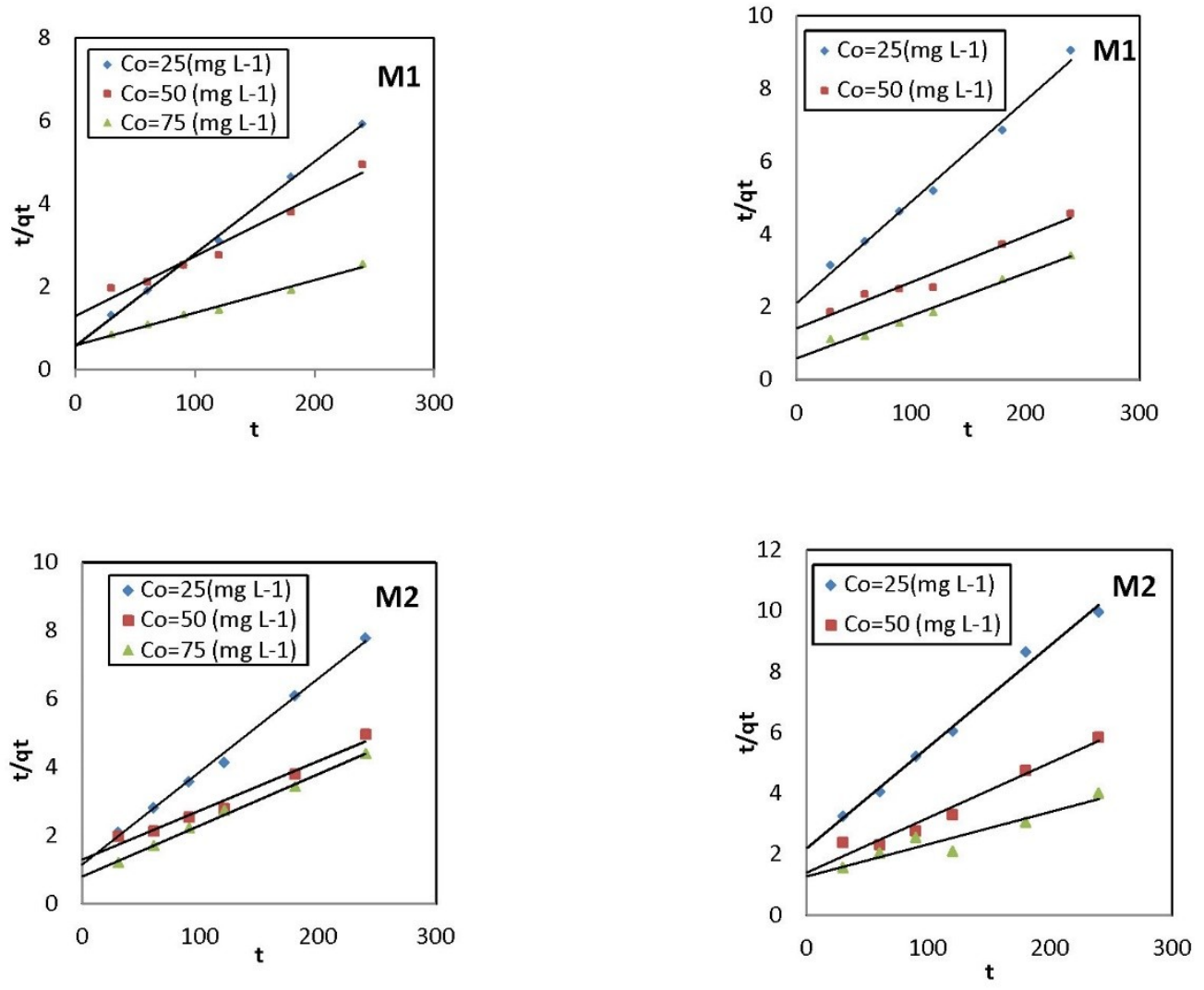

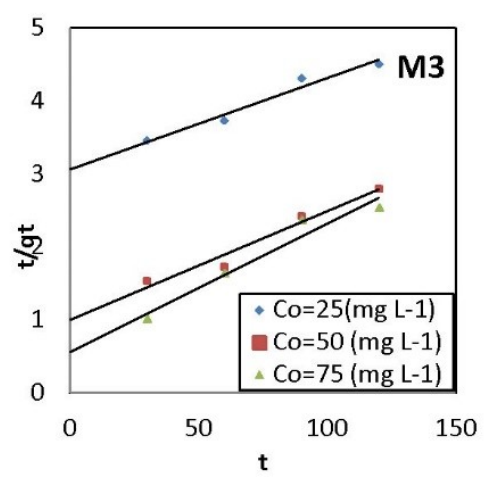

a

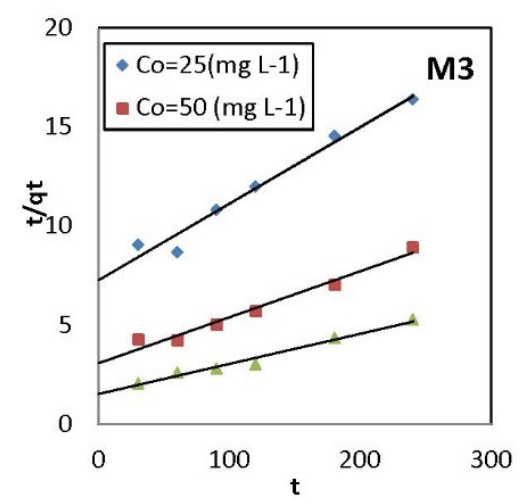

b

Figure 6. Plots for the pseudo-second-order kinetic model a:MB adsorption b:MG adsorption. 
Table 1. Parameters for pseudo-first and second-order kinetic models

\begin{tabular}{|c|c|c|c|c|c|c|c|c|c|}
\hline \multirow[b]{2}{*}{ Dye } & \multirow[b]{2}{*}{ Adsorbent } & \multirow[b]{2}{*}{$\begin{array}{c}\text { Co } \\
\left(\mathrm{mg} \mathrm{L}^{-1}\right)\end{array}$} & \multirow[b]{2}{*}{$\begin{array}{c}\mathrm{qe}_{\mathrm{e}} \exp \\
\left(\mathrm{mg} \mathrm{g}^{-1}\right)\end{array}$} & \multicolumn{3}{|c|}{ Pseudo-first } & \multicolumn{3}{|c|}{ Pseudo-second } \\
\hline & & & & $\begin{array}{c}\mathrm{qe}_{\mathrm{e}} \mathrm{C} \\
\left(\mathrm{mg} \mathrm{g}^{-1}\right)\end{array}$ & $\begin{array}{c}\mathrm{k}_{1} \\
\left(\mathrm{~min}^{-1}\right)\end{array}$ & $\mathrm{R}^{2}$ & $\begin{array}{c}\mathrm{qe}_{\mathrm{e}} \mathrm{C} \\
\left(\mathrm{mg} \mathrm{g}^{-1}\right)\end{array}$ & $\begin{array}{c}\mathrm{k}_{2} \\
\left(\mathrm{~g} \mathrm{mg}^{-1} \mathrm{~min}^{-1}\right)\end{array}$ & $\mathrm{R}^{2}$ \\
\hline \multirow[t]{9}{*}{ MB } & & 25 & 38.48 & 38.26 & 0.0286 & 0.999 & 44.84 & 1.7379 & 0.990 \\
\hline & M1 & 50 & 68.77 & 71.98 & 0.0334 & 0.998 & 54.35 & 2.1119 & 0.995 \\
\hline & & 75 & 82.81 & 83.37 & 0.0184 & 0.999 & 126.58 & 1.6750 & 0.988 \\
\hline & & 25 & 28.96 & 28.85 & 0.0221 & 0.999 & 36.63 & 0.8669 & 0.995 \\
\hline & M2 & 50 & 47.05 & 48.38 & 0.0292 & 0.998 & 54.35 & 2.1119 & 0.995 \\
\hline & & 75 & 43.90 & 44.52 & 0.0286 & 0.999 & 66.67 & 1.2279 & 0.991 \\
\hline & & 25 & 26.63 & 28.14 & 0.0170 & 0.992 & 80.00 & 0.3259 & 0.962 \\
\hline & M3 & 50 & 43.66 & 47.11 & 0.0269 & 0.992 & 71.43 & 0.9747 & 0.969 \\
\hline & & 75 & 38.47 & 39.25 & 0.0511 & 0.999 & 42.55 & 3.7092 & 0.998 \\
\hline \multirow[t]{9}{*}{ MG } & & 25 & 23.10 & 24.13 & 0.0205 & 0.996 & 36.10 & 0.4684 & 0.990 \\
\hline & M1 & 50 & 47.02 & 49.07 & 0.0154 & 0.981 & 79.37 & 0.7039 & 0.959 \\
\hline & & 75 & 64.13 & 69.25 & 0.0246 & 0.991 & 86.21 & 16.4069 & 0.984 \\
\hline & & 25 & 19.80 & 20.22 & 0.0228 & 0.999 & 30.03 & 0.4523 & 0.991 \\
\hline & M2 & 50 & 36.17 & 41.94 & 0.0249 & 0.984 & 55.56 & 0.7068 & 0.963 \\
\hline & & 75 & 56.80 & 54.31 & 0.0106 & 0.985 & 94.34 & 0.7780 & 0.903 \\
\hline & & 25 & 9.98 & 10.79 & 0.0205 & 0.987 & 25.91 & 0.1367 & 0.970 \\
\hline & M3 & 50 & 20.92 & 23.26 & 0.0214 & 0.982 & 43.29 & 0.3201 & 0.972 \\
\hline & & 75 & 39.28 & 41.64 & 0.0177 & 0.980 & 65.36 & 0.6468 & 0.978 \\
\hline
\end{tabular}

Table 1 summarises the suitable results obtained from the two models. It can be seen from the results that the correlation coefficients of the pseudo-first-order model are higher than the pseudo-second-order. Thus, the pseudo-firstorder-model was adopted to describe the process. Besides, the experimental adsorption capacities of two dyes onto mushrooms were closer to pseudofirst-order values. This result indicates that the number of free sites was significantly higher than the number of adsorbed dye molecules and reveals that the adsorption between dyes and biosorbents was physisorption which leads to a slow adsorption process. Furthermore, the pseudo-first-order model shows the effect of adsorption at the solidliquid interface, indicating that the mushrooms had a certain affinity to the dye molecules (31).

\section{Evaluation of biosorption isotherms}

Two isotherm models namely, Freundlich and Langmuir, were used to identify the adsorption equilibrium. The equation for the Freundlich and Langmuir models predicated as in the Eqs.3 and 4:

$\ln q_{e}=\ln K_{F}+\left(1 / n_{F}\right) \ln C_{e}$
$\mathrm{C}_{\mathrm{e}} / \mathrm{q}_{\mathrm{e}}=1 / b \mathrm{q}_{\mathrm{m}}+\mathrm{C}_{\mathrm{e}} / \mathrm{q}_{\mathrm{m}}$

where $\mathrm{C}_{e}$ is the equilibrium concentration $\left(\mathrm{mg} \mathrm{L}^{-1}\right)$, $\mathrm{q}_{\mathrm{e}}$ is the adsorption amount (mg $\mathrm{g}^{-1}$ ) at equilibrium, $\mathrm{q}_{\mathrm{m}}$ is the theoretical maximum adsorption capacity ( $\mathrm{mg} \mathrm{g}^{-1}$ ) and $b$ is Langmuir constant representing the enthalpy of sorption while $\mathrm{K}_{\mathrm{F}}$ and $\mathrm{n}_{\mathrm{F}}$ are the Freundlich constants related to the biosorption capacity $\left(\mathrm{mg} \mathrm{g}^{-1}\right)$ and biosorption intensity or heterogeneity of the adsorbent, respectively. According to the Langmuir isotherm model, all the adsorption sites were the same and dynamically equivalent due to the monolayer adsorption. In the case of the Freundlich isotherm model, the adsorption caused by a heterogeneous mechanism. The calculated parameters of both models are summarized in Table 2 and it can be seen that the Freundlich isotherm model is well fitted with the biosorption of all mushrooms onto two dye processes because of their high $\mathrm{R}^{2}$ values. Furthermore, the $1 / \mathrm{n}$ values which were in a range of $0-1$ indicated favourability of the adsorption of the mushrooms onto the MB and $M G$ dyes. The equilibrium isotherms are presented in Figure 7. 
Table 2. Parameters for the Langmuir and Freundlich isotherm models

\begin{tabular}{|c|c|c|c|c|c|c|c|c|}
\hline \multirow[b]{2}{*}{ Dye } & \multirow[b]{2}{*}{ Mushroom } & \multirow[b]{2}{*}{$\mathrm{T}(\mathrm{K})$} & \multicolumn{3}{|c|}{ Freundlich } & \multicolumn{3}{|c|}{ Langmuir } \\
\hline & & & $\mathrm{K}_{\mathrm{F}}$ & $\mathrm{n}$ & $\mathrm{R}^{2}$ & $\mathrm{q}_{\mathrm{m}}$ & $b$ & $\mathrm{R}^{2}$ \\
\hline \multirow{9}{*}{ MB } & \multirow{3}{*}{ M1 } & 303 & 9.34 & 1.76 & 0.9888 & 114.94 & 0.04 & 0.9818 \\
\hline & & 313 & 7.23 & 1.86 & 0.9868 & 87.72 & 0.04 & 0.9454 \\
\hline & & 323 & 5.87 & 1.86 & 0.9932 & 69.93 & 0.04 & 0.9931 \\
\hline & \multirow{3}{*}{ M2 } & 303 & 5.71 & 1.62 & 0.9919 & 102.04 & 0.03 & 0.9715 \\
\hline & & 313 & 9.35 & 1.27 & 0.9972 & 142.86 & 0.01 & 0.9788 \\
\hline & & 323 & 2.59 & 1.43 & 0.9952 & 86.96 & 0.02 & 0.9715 \\
\hline & \multirow{3}{*}{ M3 } & 303 & 2.75 & 1.29 & 0.9929 & 144.93 & 0.01 & 0.9089 \\
\hline & & 313 & 1.68 & 1.21 & 0.9928 & 80.65 & 0.01 & 0.9721 \\
\hline & & 323 & 1.34 & 1.20 & 0.9906 & 53.48 & 0.02 & 0.9727 \\
\hline \multirow{9}{*}{ MG } & \multirow{3}{*}{ M1 } & 303 & 2.51 & 1.25 & 0.9983 & 163.93 & 0.01 & 0.9614 \\
\hline & & 313 & 3.51 & 1.51 & 0.9977 & 69.93 & 0.06 & 0.9722 \\
\hline & & 323 & 2.48 & 1.44 & 0.9942 & 28.41 & 0.06 & 0.9744 \\
\hline & \multirow{3}{*}{ M2 } & 303 & 2.03 & 1.21 & 0.9810 & 166.67 & 0.01 & 0.9799 \\
\hline & & 313 & 2.36 & 1.37 & 0.9870 & 100.00 & 0.01 & 0.9836 \\
\hline & & 323 & 1.86 & 1.43 & 0.9929 & 65.79 & 0.02 & 0.9927 \\
\hline & \multirow{3}{*}{ M3 } & 303 & 1.87 & 1.23 & 0.9977 & 144.93 & 0.01 & 0.9727 \\
\hline & & 313 & 1.79 & 1.36 & 0.9906 & 77.52 & 0.01 & 0.9823 \\
\hline & & 323 & 1.50 & 1.40 & 0.9974 & 61.73 & 0.01 & 0.9781 \\
\hline
\end{tabular}
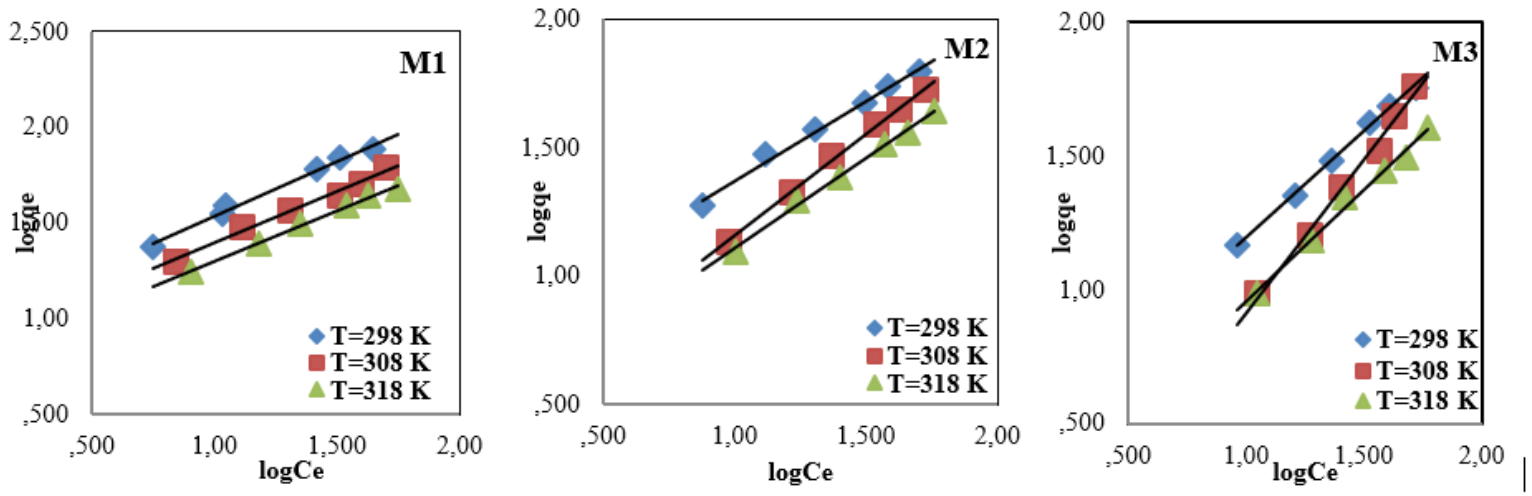

a
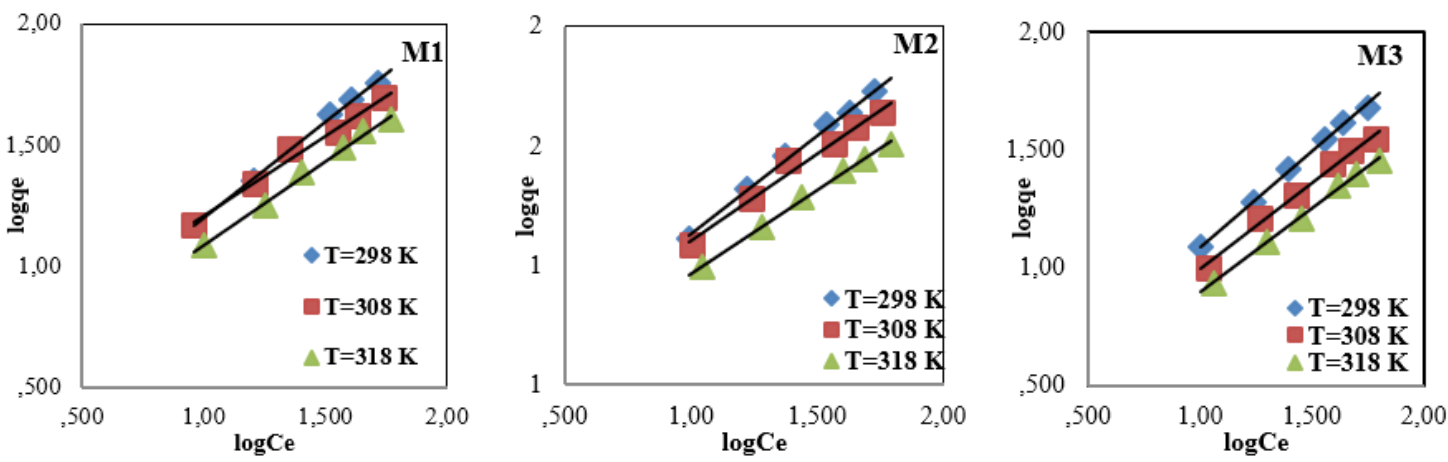

b

Figure 7. The plot of the Freundlich isotherm model a: MB, b: MG.

Besides, as shown in Table 2, theoretical adsorption capacity, $\mathrm{q}_{\mathrm{m}}$, decreased with increasing temperature remarking that the adsorptions of $M 1$, M2, M3 on the MB and MG are favorable at lower temperatures. Also, the maximum adsorption capacities (Table 2) of M1, M2, M3 were determined as $82.81,47.40$ and $43.90 \mathrm{mg} \mathrm{g}^{-1}$ for
MB and $64.13,56.80$ and $39.28 \mathrm{mg} \mathrm{g}^{-1}$ for MG adsorption at $303 \mathrm{~K}$, respectively. Similarly, in the study of Yan and Wang (2013), the $\mathrm{q}_{\mathrm{m}}$ was found as $63.5 \mathrm{mg} \mathrm{g}^{-1}$ for the adsorption of methylene blue by the spent mushroom substrate (32). 


\section{Thermodynamics of biosorption}

To investigate the nature of the biosorption process of both cationic dyes onto M1, M2, M3, thermodynamic studies were applied. In this study, the thermodynamic equilibrium constant $K_{0}$ for the biosorption process was carried out by plotting $\ln \left(Q_{e} / C_{e}\right)$ versus $Q_{e}$ in the temperature range of 303-323 K. Besides, thermodynamic parameters such as $\Delta H^{0}$ enthalpy change and $\Delta S^{0}$ entropy change were calculated from Eq. 5 that was based on the slope and intercept of the Van't Hoff plots (InKo vs $1 / T$, not shown) and the values of $\Delta G^{0}$ Gibbs free energy change was calculated using Eq.6 (33):

$\ln K=\Delta S^{0} / \mathrm{R}-\Delta H^{0} / R(1 / T)$

$\Delta G^{0}=-R T \ln K_{0}$ where $K_{0}$ is the equilibrium constant, $T$ is the solution temperature $(\mathrm{K})$ and $R$ is the gas constant $\left(8.314 \mathrm{~J} \mathrm{~mol}^{-1} \mathrm{~K}^{-1}\right)$.

The related parameters are presented in Table 3. As can be seen from the table, the negative values of $\Delta G^{0}$ show that the adsorption of two cationic dyes onto the mushrooms is spontaneous and feasible. The negative value of change in enthalpy $\left(\Delta H^{0}\right)$ indicates that the adsorption was an exothermic process. Since all values of $\Delta H^{0}$ are smaller than $40 \mathrm{~kJ} / \mathrm{mol}$, the adsorption of $M B$ and MG onto $M 1, M 2$ and $M 3$ was a physisorption process. Furthermore, the positive value of change in entropy $\left(\Delta S^{0}\right)$ indicates the increasing randomness while negative value (MG adsorption of M2, M3) proves that the randomness of the solid/solution interface decreased during the adsorption process 
Table 3. Thermodynamic parameters for $M B, M G$ dyes on $M 1, M 2, M 3$.

\begin{tabular}{|c|c|c|c|c|c|}
\hline Dye & Mushroom & $\mathrm{T}(\mathrm{K})$ & $\Delta \mathrm{G}(\mathrm{kJ} / \mathrm{mol})$ & $\Delta \mathrm{H}(\mathrm{kJ} / \mathrm{mol})$ & $\Delta \mathrm{S}(\mathrm{kJ} / \mathrm{molK})$ \\
\hline \multirow{9}{*}{$\mathrm{MB}$} & \multirow{3}{*}{ M1 } & 303 & -24.82 & \multirow{3}{*}{-23.16} & \multirow{3}{*}{3.49} \\
\hline & & 313 & -22.97 & & \\
\hline & & 323 & -24.97 & & \\
\hline & \multirow{3}{*}{ M2 } & 303 & -24.75 & \multirow{3}{*}{-8.88} & \multirow{3}{*}{54.32} \\
\hline & & 313 & -27.13 & & \\
\hline & & 323 & -25.76 & & \\
\hline & \multirow{3}{*}{ M3 } & 303 & -26.57 & \multirow{3}{*}{-16.04} & \multirow{3}{*}{36.2} \\
\hline & & 313 & -28.31 & & \\
\hline & & 323 & -27.24 & & \\
\hline \multirow{9}{*}{ MG } & \multirow{3}{*}{ M1 } & 303 & -24.57 & \multirow{3}{*}{-0.5} & \multirow{3}{*}{79.47} \\
\hline & & 313 & -25.38 & & \\
\hline & & 323 & -26.16 & & \\
\hline & \multirow{3}{*}{ M2 } & 303 & -26.85 & \multirow{3}{*}{-39.21} & \multirow{3}{*}{-60.01} \\
\hline & & 313 & -25.67 & & \\
\hline & & 323 & -25.68 & & \\
\hline & \multirow{3}{*}{ M3 } & 303 & -26.48 & \multirow{3}{*}{-38.12} & \multirow{3}{*}{-47.15} \\
\hline & & 313 & -25.40 & & \\
\hline & & 323 & -25.53 & & \\
\hline
\end{tabular}

Table 4. Comparison of adsorption capacity of $M B$, MG dyes on $M 1, M 2, M 3$ with other biosorbents.

\begin{tabular}{|c|c|c|c|}
\hline Adsorbent & dye & $\begin{array}{c}\text { Adsorption capacity } \\
\left(\mathrm{mg} \mathrm{g}^{-1}\right)\end{array}$ & Reference \\
\hline Activated carbon & MG & 57.03 & $(34)$ \\
\hline Luffa aegyptica peel & MG & 70.22 & $(35)$ \\
\hline Pleurotus ostreatus & MG & 32.35 & $(36)$ \\
\hline Trichoderma viride & MB & 201.50 & (37) \\
\hline Carica papaya wood & $\begin{array}{l}\text { MG } \\
\text { MB }\end{array}$ & $\begin{array}{l}52.63 \\
32.25 \\
\end{array}$ & $(38)$ \\
\hline Phellinus igniarius fungi & MB & 232.21 & (39) \\
\hline Aspergillus fumigatus & MB & 125.07 & $(40)$ \\
\hline Corynebacterium glutamicum & MB & 207.30 & $(41)$ \\
\hline $\begin{array}{l}\text { M1 } \\
\text { M2 } \\
\text { M3 } \\
\end{array}$ & MB & $\begin{array}{l}82.81 \\
43.90 \\
38.47\end{array}$ & This study \\
\hline $\begin{array}{l}\text { M1 } \\
\text { M2 } \\
\text { M3 }\end{array}$ & MG & $\begin{array}{l}64.13 \\
56.80 \\
39.28 \\
\end{array}$ & This study \\
\hline
\end{tabular}

\section{CONCLUSIONS}

In the present study, the $M 1, M 2$ and $M 3$ mushrooms were used as adsorbents for the investigation of $M B$ and $M G$ adsorption. The maximum adsorption capacity of $\mathrm{M} 1, \mathrm{M} 2, \mathrm{M} 3$ was found as $82.81,43.90$ and $38.47 \mathrm{mg} \mathrm{g}^{-1}$ for the $M B$ dye and $64.13,56.80$ and $39.28 \mathrm{mg} \mathrm{g}^{-1}$ for the $M G$ dye, respectively. The adsorption capacity of both dyes was found to increase with increasing $\mathrm{pH}$ from 3 to 11 . The kinetic data were well fitted to pseudo-first-order. The isotherm data were in good agreement with the Freundlich isotherm model. All the results showed that the adsorption was exothermic. The studies in the literature also support the results of the present study by stating that the adsorption of MB and MG cationic dyes onto mushrooms is quite convenient.

\section{REFERENCES}

1. Wu J, Zhang T, Chen C, Feng L, Su X, Zhou L, Chen $Y$, Xia A, Wang $X$. Spent substrate of Ganodorma lucidum as a new bio-adsorbent for adsorption of three typical dye. Bioresource Technology. 2018; 266: 134-8.

2. Gao Y, Deng SQ, Jin X, Cai SL, Zheng SR, Zhang WG. The construction of amorphous metal-organic 
cage-based solid for rapid dye adsorption and time-dependent dye separation from water. Chemical Engineering Journal. 2019; 357: 129-39.

3. Molla A, Li Y, Mandal B, Gu Kang S, Hur SH, Chung JS. Selective adsorption of organic dyes on graphene oxide: Theoretical and experimental analysis. Applied Surface Science. 2019; 464: 170-7.

4. Wang $X$, Jiang $C$, Hou B, Wang $Y$, Hao C, Wu JX. Carbon composite lignin-based adsorbents for the adsorption of dyes. Chemosphere 20. 2018; 6: 587-96.

5. Yeşilada Ö. Decolorization of Crystal Violet by Fungi, World Journal of Microbiology and Biotechnology. 1995; 11: 601-2.

6. Kunamneni A, Ghazi I, Camarero S, Ballesteros A, Plou FJ, Alcalde M. Decolorization of synthetic dyes by laccase immobilized on epoxyactivatedcarriers. Process Biochemistry. 2008; 43(2): 169-78.

7. Wesenberg D, Buchon F, Agathos SN. Degradation of Dye Containing Textile Effluent by Agaric White - Rot Fungus Clitocybula dusenii. Biotechnology Letters. 2002; 24: 989-93.

8. Stainer RY, Adelberg EA, Ingraham J. The Microbial World" Prentic Hall. Inc. Englewood Cliffs. New Jersey. 1976; 105-18.

9. Jaspers CJ, Penninck MJ. Adsorption Effects On the Decolorization of a Craftblach Plant Effluent by Phanerochaete chrysosporium. Biotechnology Letters. 1996; 11(18): 1257-60.

10. Couto SR. Rivela I. Munos MR, Sanroman A. Ligninolytic Enzyme Production and The Ability of Decolourisation of Poly R-478 in Packed Bed Bioreactors by Phanerochaete chrysosporium. Bioprocess Engineering.2000; 23: 287-93.

11. Wang $Y, Y u$ J. Adsorption and Degradation of Synthetic Dyes on the Mycelium of Trametes versicolor. Water Science Technology. 1998; 45(38): 233-8.

12. Poverenov E, Arnon-Rips H, Zaitsev $\mathrm{Y}$, Bar V, Danay O, Horev B, Bilbao-Sainz C, McHugh T, Rodo $V$. Potential of chitosan from mushroom waste to enhance quality andstorability of fresh-cut melons. Food Chemistry. 2018; 268: 233-41.

13. Kurt A, Gençcelep $H$. Enrichment of meat emulsion with mushroom (Agaricus bisporus) powder: Impact on rheological and structural characteristics. Journal of Food Engineering. 2018; 237: $128-36$.

14. Sewu DD, Boakye $P$, Jung $H$, Woo $S H$. Synergistic dye adsorption by biochar from copyrolysis of spent mushroom substrate and Saccharina japonica. Bioresource Technology.
2017; 244: 1142-9.

15. Kariuki Z, Kiptoo J, Onyanch D. Biosorption studies of lead and copper using rogers mushroom biomass 'Lepiota hystrix'. South african journal of chemical engineering. 2017; 23: 62-70.

16. Kamasonlian S, Balomajumder C, Chand S, Suresh S. Biosorption of $\mathrm{Cd}(\mathrm{II})$ and $\mathrm{As}$ (III) ions from aqueous solution by tea waste biomass. Afr. J. Environ. Sci. Technol. 2011; 5(1):1-7.

17. Negm NA, Wahed MGAE, Hassan ARA, Kana MTHA. Feasibility of metal adsorption using brown algae and fungi: Effect of biosorbents structure on adsorption isotherm and kinetics Journal of Molecular Liquids. 2018; 264: 292-305.

18. Auta M, Hameed BH. Chitosan-clay composite as highly effective and low cost adsorbent for bathch and fixed-bed adsorption of methylene blue. Chemical Engineering Journal. 2014; 237: 352-61.

19. Karadirek Ş, Okkay H. Statistical modeling of activated carbon production from spent mushroom compost. Journal of Industrial and Engineering Chemistry. 2018; 63: 340-7.

20. Hu S, Hsieh Y. Preparation of Activated Carbon and Silica Particles from Rice Straw. ACS Sustain, Chem. Eng. 2014; 2(4): 726.

21. Mahmoud ME, Nabil GM,. El-Mallah NM, Bassiouny HI, Kumar S, Abdel-Fattah TM. Kinetics, isotherm, and thermodynamic studies of the adsorption of reactive red 195 A dye from water by modified Switchgrass Biochar adsorbent. J. Ind. Eng. Chem. 2016; (37) 156. https://doi.org:10.1016/j.jiec.2016.03.020.

22. Budnyak TM, Aminzadeh S, Pylypchuk IV, Sternik D, Tertykh VA, Lindström ME, Sevastyanova O. Methylene Blue dye sorption by hybrid materials from technical lignins. Journal of Environmental Chemical Engineering. 21018; 6: 4997-5007.

23. Zahira A, Aslam Z, Kamal MS, Ahmad W, Abbas A, Shawabk RA. Development of novel cross-linked chitosan for the removal of anionic Congo red dye. Journal of Molecular Liquids. 2017; 244: 211-8.

24. Singh S, Gaikwad KK, Lee $M$, Lee $Y S$. Thermally buffered corrugated packaging for preserving the postharvest freshness of mushrooms (Agaricus bispours). Journal of Food Engineering. 2018; 216: 11-9.

25. Tong DS, Wu CW, Adebajo MO, Jin GC, Yu WH, Ji SF, Zhou CH. Adsorption of methylene blue from aqueous solution onto porous cellulose derived carbon/montmorillonite nanocomposites. Applied Clay Science. 2018; 161(1): 256-64. 
26. Auta M, Hameed BH. Chitosan-clay composite as highly effective and low-cost adsorbent for batch and fixed-bed adsorption of methylene blue. Chemical Engineering Journal. 2014; 237: 352-61.

27. Liu X, Lee DJ. Thermodynamic parameters for adsorption equilibrium of heavy metals and dyes from wastewaters. Bioresource Technology. 2014; 160: 24-31.

28. Ishmaturrahmi $R$, Mustafa I. Methylene blue removal from water using $\mathrm{H} 2 \mathrm{SO} 4$ crosslinked magnetic chitosan nanocomposite beads. Microchemical Journal. 2019; 144: 397-402.

29. Ho YS, McKay G. Review of second-order models for adsorption systems, Chem. Eng. J. 1998; 70: 115-24. https://doi.org/10.1016/j.jhazmat.2005.12.043.

30. Ho YS, McKay G. Pseudo-second order model for sorption processes, Process Biochem. 1999; 34: 451-65, https://doi.org/10.1016/S00329592(98)00112-5.

31. Ai T, Jianga X, Liu Q, Lv L, Wu H. Daptomycin adsorption on magnetic ultra-fine wood-based biochars from water: Kinetics, isotherms, and mechanism studies. Bioresource Technology. 2019; 273: 8-15.

32. Yan T, Wang L. Adsorptive Removel of Methylene blue from Aqueous Solution by spent mushroom substrate: Equilibrum, Kinetics, and Thermodynamics. BioResources. 2013; 8(3): 4722-34.

33. Wong S, Tumari $\mathrm{HH}$, Ngadi N, Mohamed NB, Hassan O, Mat R, Amin NAS. Adsorption of anionic dyes on spent tea leaves modified withpolyethyleneimine (PEI-STL). Journal of Cleaner Production. 2019; 206: 394-406.

34. Rahman IA, Saad B, Shaidan, Sya Rizal E S .
Adsorption characteristics of malachite green on activated carbon derived from rice husks produced by chemical-thermal process. Bioresource Technology. 2005; 96(14):1578-83.

35. Mashkoor F, Nasar A. Preparation, characterization and adsorption studies of the chemicallymodifiedLuffa aegypticapeel as a potential adsorbent for the removal ofmalachite green from aqueous solution. Journal of Molecular Liquids. 2019; 274:315-27.

36. Chen $Z$, Deng $H$, Chen $C$, Yang $Y, X u H$. Biosorption of malachite green from aqueous solutions by Pleurotus ostreatus using Taguchi method. Journal of Environmental Health Science \& Engineering. 2014; 12: 63.

37. Saeed A, Iqbal M, Zafar S I. Immobilization of Trichoderma viride for enhanced methylene blue biosorption: Batch and column studies. Journal of Hazardous Materials. 2009; 168(1): 406-15.

38. Rangabhashiyam S, Lata S, Balasubramanian P. Biosorption characteristics of methylene blue and malachite green from simulated wastewater onto Carica papaya wood biosorbent. Surfaces and Interfaces. 2018; 10: 197-215.

39. Maurya N S, Mittal A K, Cornel P, Rother E. Biosorption of dyes using dead macro fungi: Effect of dye structure, ionic strength and $\mathrm{pH}$. Bioresource Technolog. 2006; (7)3:512-21.

40. Abdallah R, Taha S. Biosorption of methylene blue from aqueous solution by nonviable Aspergillus fumigatus. Chemical Engineering Journal. 2012; 195-196, 69-76.

41. Vijayaraghavan K, Won S W, Mao J, Yun Y-S. Chemical modification of Corynebacterium glutamicum to improve methylene blue biosorption. Chemical Engineering Journal.2008; 145(1): 1-6. 